\title{
Water quality and antibiotic resistance at beaches of the Galápagos Islands
}

\author{
Katie N. Overbey, Sarah M. Hatcher and Jill R. Stewart *
}

Department of Environmental Sciences and Engineering, Gillings School of Global Public Health, University of North Carolina, Chapel Hill, NC, USA

\section{OPEN ACCESS}

Edited by:

Erin Katherine Lipp,

University of Georgia, USA

Reviewed by:

Gian Marco Luna,

National Research Council - Institute

of Marine Sciences, Italy

Dale Warren Griffin,

US Geological Survey, USA

*Correspondence:

Jill R. Stewart,

Department of Environmental

Sciences and Engineering, Gillings

School of Global Public Health,

University of North Carolina, Campus

Box 7431, Chapel Hill, NC 27599,

USA

jill.Stewart@unc.edu

Specialty section:

This article was submitted to

Environmental Health,

a section of the journal

Frontiers in Environmental Science

Received: 03 July 2015

Accepted: 14 September 2015

Published: 09 October 2015

Citation:

Overbey KN, Hatcher SM and Stewart JR (2015) Water quality and antibiotic resistance at beaches of the

Galápagos Islands.

Front. Environ. Sci. 3:64.

doi: 10.3389/fenvs.2015.00064
Tourism and residential population growth are increasing on the Galápagos Islands, yet the effects of this growth on environmental quality are not well understood. The goal of this study was to characterize recreational water quality on one of the inhabited islands of the Galápagos (Isla San Cristóbal). Five beaches were sampled to allow a comparison between beaches with and without discharge of human sewage, and to help elucidate the effects of human activities in this unique environment. Enterococcus concentrations were quantified using IDEXX Enterolert ${ }^{\circledR}$ and antibiotic resistance testing was performed on Escherichia coli isolated by membrane filtration. All study beaches sometimes exceeded international guidelines for recreational water quality, and significantly higher Enterococcus concentrations were found near sites subjected to sewage discharge $(p<0.01)$. These sewage-impacted sites also had higher levels of antibiotic resistant E. coli, suggesting that human activities are increasing the levels of resistance that would occur naturally. Future studies should characterize the extent of this impact both spatially and temporally. The results of this study demonstrate that sewage can contribute antibiotic resistant bacteria to marine waters and suggest that human impacts in the Galápagos Islands extend to the environmental resistome. This impact is likely common in areas across the globe wherever tourists frequently carry and use antibiotics.

Keywords: Galapagos Islands, recreational water quality, Enterococcus, antibiotic-resistant E. coli, sewage

\section{Introduction}

On the Galápagos Islands, a recent increase in land-based tourism and a growing local population are increasing the amount of raw sewage being discharged into local waters. Sewage treatment systems on the islands are either not present, or are frequently dysfunctional or not in operation. This wastewater may pose a potential public health risk and may threaten the habitats which comprise the unique ecosystem that sustains the growing economy (Epler, 2007; Watkins and Cruz, 2007; Walsh et al., 2010). The Galápagos Islands have a residential population of about 30,000 and almost 200,000 tourists visit the islands each year (Epler, 2007; Galapagos National Park Service, 2010). The number of tourists visiting the islands is increasing, which drives population growth as more people from the mainland move to the Galápagos in hopes of working in the tourism sector (Walsh et al., 2010). Many of the tourists are attracted to the islands because they are marketed as pristine, and because they are home to a wide array of unique flora and fauna (deGroot, 1983; Walsh et al., 2010). 
In coastal environments, one especially problematic consequence of human population growth is the uncontrolled release of human waste, which can severely degrade the quality of recreational waters (Jackson et al., 2001; Howarth et al., 2002; Dwight et al., 2004). The release of human, animal, and industrial sewage is the number one contributor of waste into the oceans and is a major source of nutrient input, leading to environmental damage and eutrophication (Nixon, 1995; Prüss, 1998; Shahidul Islam and Tanaka, 2004). Sewage release can also increase mortality of marine organisms (Hernández et al., 1998) and infect these animals with pathogens (Bossart et al., 1990). The quality of recreational waters is not only critical to environmental health, but is also closely tied to human health (Fleming et al., 2006).

The presence of human sewage in recreational waters can cause a range of negative health outcomes in exposed humans, most notably gastrointestinal illness and skin infections (Fleisher et al., 1998; Wade et al., 2003; Colford et al., 2007). Previous studies have reported that levels of fecal indicator bacteria (FIB) in recreational waters are associated with gastrointestinal illness and that a dose-response relationship exists between FIB concentrations and levels of illness in recreational water impacted by sewage discharge (Prüss, 1998; World Health Organization (WHO), 2003; Fewtrell and Kay, 2015). A meta-analysis of epidemiology studies found that enterococci were associated with an increase in gastrointestinal illness in marine waters, with a one $\log$ increase in Enterococcus correlating with a 1.34 increase in relative risk (Wade et al., 2003).

An additional danger of sewage discharge is the potential for the release of antibiotic-resistant bacteria into the environment (Cooke, 1976; Bell, 1978; Parveen et al., 1997; Reinthaler et al., 2003; Schwartz et al., 2003; Martins da Costa et al., 2006). In developed and developing countries, humans often carry resistant organisms in their gut, due to the use and misuse of antibiotics, potentially degraded or expired antibiotics, and unhygienic conditions allowing resistant organisms to spread (Okeke et al., 1999). The presence of antibiotic resistant bacteria in the guts of human and animals can make waste streams potential sources of antibiotic resistant bacteria in the environment. Areas that are particularly vulnerable include receiving waters downstream from municipal waste water treatment plants, hospital waste streams, and surface waters around confined animal feeding operations (Guardabassi et al., 1998; Kim and Aga, 2007; Baquero et al., 2008; Silbergeld et al., 2008). Monitoring the release of antibiotic resistant bacteria is key in understanding potential health risks (Cosgrove and Carmeli, 2003).

Antibiotic resistant pathogens have been identified as a major public health threat (Neu, 1992; Wise et al., 1998). The negative health outcomes of antibiotic resistant bacteria include more virulent pathogens, delays in the administration of appropriate antimicrobial therapy, and inadequate or even toxic therapies for treatment of resistant pathogens (Cosgrove and Carmeli, 2003). Antibiotic resistant bacteria can be classified based on the number of antibiotic classes to which they exhibit resistance, though there is still no international standard of classification. One common classification is multidrug resistance, which can be defined as an organism that exhibits resistance to three or more classes of antibiotics (Magiorakos et al., 2011). Multidrugresistant bacteria further reduce the ability to treat infections effectively (Roberts et al., 2009). Multidrug-resistant pathogens can increase patient mortality, hospital length of stay and hospital costs, thus having both an economic and human health impact (Cosgrove and Carmeli, 2003; Giske et al., 2008).

The lack of surface water quality monitoring in the Galápagos makes it difficult to understand the impacts of sewage on the environment and potential public health threats (Walsh et al., 2010). Additionally, the presence of antibiotic resistant bacteria in the recreational waters of the Galápagos has never been examined, although it is known that tourists frequently travel with antibiotics, and the US Centers for Disease Control and Prevention (CDC) recommends that travelers to Galápagos pack antibiotics so they may treat diarrhea early if they start to get sick (Richter, 2003; Centers for Disease Control and Prevention (CDC), 2014). Understanding the impact that sewage release has on water quality in the Galápagos is important for the protection of human health, environmental health, and the economy. The relatively small geographic size of the Galápagos allows for a targeted study designed to begin exploring these impacts.

The objective of this study was to determine if the presence of human wastewater is related to degradation of recreational water quality and a higher level of bacterial antibiotic resistance in the Galápagos Islands. A field campaign was undertaken to examine the impacts of human sewage on beach water quality. Sites were specifically chosen to allow for the comparison of sewage impacted sites vs. sites not impacted by sewage. Enterococcus concentrations and antibiotic resistance among E. coli at beaches with and without the presence of sewage effluent, as well as in raw sewage, were measured and compared. These results provide a baseline for water quality in an area where population and tourism growth, human health, and environmental concerns are competing. This research also improves our understanding of how human waste is contributing to the prevalence and distribution of antibiotic resistant bacteria in the environment.

\section{Materials and Methods}

\section{Site Selection}

Seven sample sites including five beaches and two sewage discharge pipes on San Cristobal Island, Galápagos, Ecuador were selected to represent areas with and without sewage effluent (Figure 1). Samples were collected at the mouths of two sewage outflow pipes which discharge at the water's surface. These two sites will be referred to as "pipe" sites. There is a sewage treatment facility on the island, but it is frequently out of service and pipes were discharging raw sewage at the time of sample collection. Samples were also collected at five beaches located at varying distances to sewage outfall points. The sites Marinos Shore (M. Shore) and Marinos Drain (M. Drain) are both relatively close to sewage outfalls, but are infrequently used for human recreation. In addition, the $M$. Drain site is at the base of a land drainage canal. Of the other three beaches, Carola is the closest to sewage outfall, Playa Mann the next closest and Tijeretas is the furthest. All three of these beaches have frequent recreational activity and a wide sand extent where swimmers can enter the water. Water from these three beaches (Carola, Playa Mann, and Tijeretas) was 


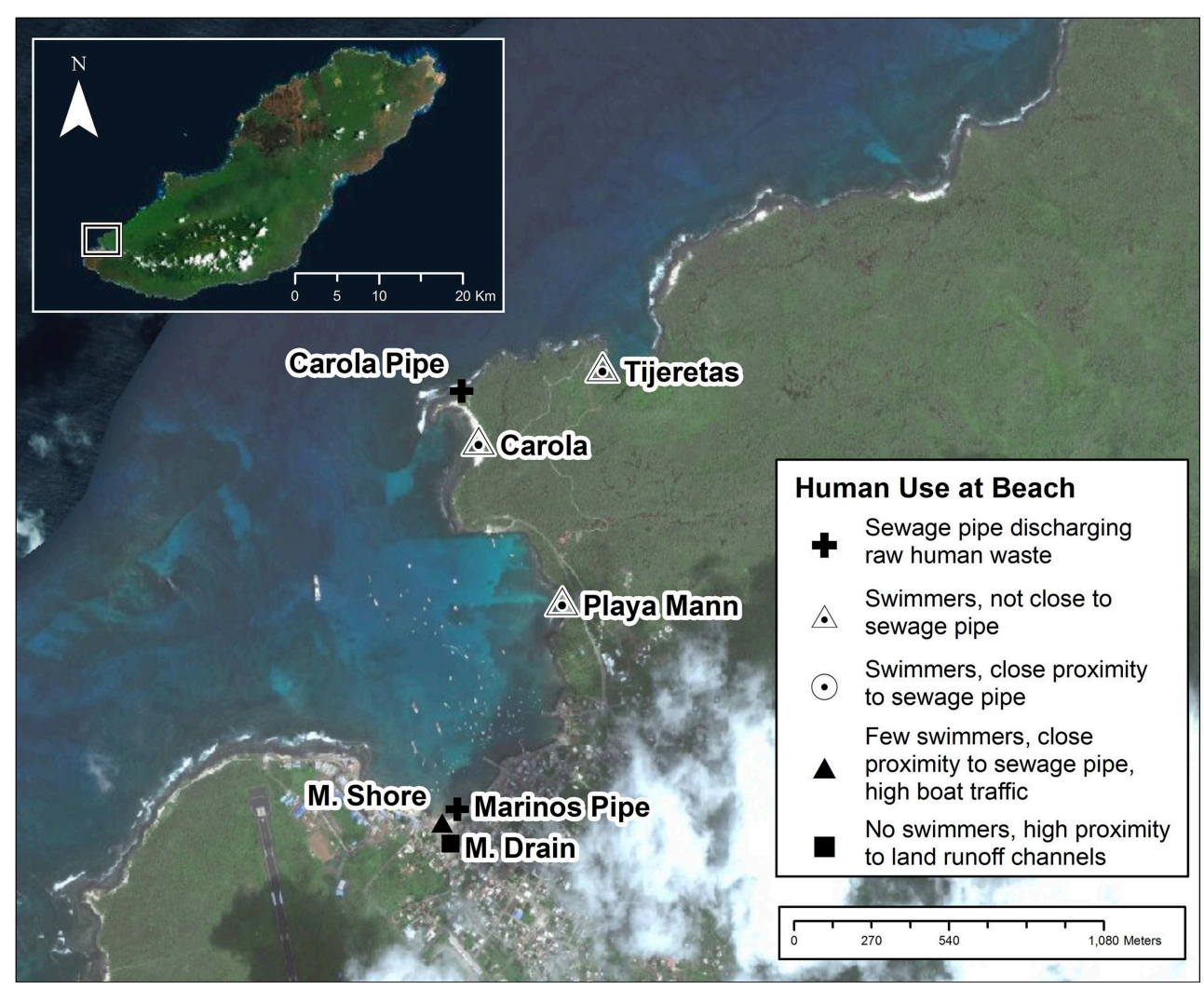

FIGURE 1 | Sample site locations and types of human use. Distances to sewage pipe are approximate and based on Euclidean measurements between points along the shoreline.

sampled from two separate sites on opposite sides of the sand extent to test for potential variation along the shoreline of the sample beach. Maps in this article were created using ArcGIS ${ }^{\circledR}$ software by Esri. ArcGIS ${ }^{\circledR}$ and $\operatorname{ArcMap}^{\mathrm{TM}}$ are the intellectual property of Esri and are used herein under license. The basemap source was: Esri, DigitalGlobe, GeoEye, Earthstar Geographics, CNES/Airbus DS, USDA, USGS, AEX, Getmapping, Aerogrid, IGN, IGP, swisstopo, and the GIS User Community.

\section{Sample Collection}

Beach water samples were collected between June 19, 2013 and July 29, 2013 on San Cristóbal Island, Galápagos Islands. Samples were collected once a week, on the same day each week, between 8:30 am and 12:00 pm local time. One hundred $\mathrm{mL}$ of water were collected from the water's surface at each sampling location in a sterile bottle at approximately $0.6 \mathrm{~m}$ depth (knee height). Two samples were collected at every beach site, but for the sites with a wide sand extent (Carola, Playa Mann, and Tijeretas) water was sampled from two separate sites on opposite sides of the area of the sand extent. This was done to account for potential variation along the shoreline of these beaches. For each beach, an analysis of variance (ANOVA) found no significant difference between the two sites sampled $(p>0.1)$.

Samples were collected regardless of rain events, though major rain events did not occur during this time period as it was the dry season. The samples were held on ice in a cooler for the duration of sampling and then refrigerated at $4^{\circ} \mathrm{C}$ until processing. All samples were processed within $6 \mathrm{~h}$ of sample collection. An additional sample of raw sewage from the municipal sewage collection center was collected in the summer of 2014 and used only in tests for antibiotic resistance.

\section{Analysis of Enterococcus}

Baseline water quality was measured using Enterococcus as an indicator in accordance with international standards including guidelines established by the World Health Organization and the US Environmental Protection Agency [(World Health Organization (WHO), 2003; U.S. Environmental Protection Agency (EPA), 2012)]. Before performing analyses, the water samples were diluted by mixing $10 \mathrm{~mL}$ of sample with $90 \mathrm{~mL}$ of commercially filtered bottled water. Negative control samples were also analyzed to confirm absence of Enterococcus in the bottled water. The IDEXX Enterolert ${ }^{\circledR}$ kit (IDEXX Laboratories, Inc., Westbrook, ME) was used to determine levels of Enterococcus in the samples according to the manufacturer's instructions. The number of wells in the Quanti-Tray ${ }^{\circledR} / 2000$ that fluoresced after incubation was counted and used to calculate the most probable number (MPN) of Enterococcus per $100 \mathrm{~mL}$ of sample. This test has a minimum limit of detection of 10 $\mathrm{MPN} / 100 \mathrm{~mL}$ and a maximum limit of detection of 24,196 $\mathrm{MPN} / 100 \mathrm{~mL}$. 
Enterococcus cultured by the Enterolert method were not further subjected to antibiotic resistance testing because: (1) the test relies on growth of bacteria in a culture broth that likely selects certain bacteria while masking out other strains that may have been present; (2) the method is capable of enriching a number of different Enterococcus species and sometimes nonEnterococcal bacteria (Ferguson et al., 2013), so that additional steps would have been necessary to isolate and speciate bacteria prior to antibiotic susceptibility testing; and (3) Enterococci are often intrinsically resistant to a number of antibiotics due to chromosomal resistance genes (Huycke et al., 1998; Jain and Marothi, 2014). Instead, antibiotic resistance testing was performed on E. coli isolated by membrane filtration. Escherichia coli is also an indicator of fecal contamination but it was a better choice for antibiotic resistance testing because we were able to specifically isolate this species from others on the culture media and because membrane filtration allows various strains of the bacteria to be independently isolated as separate colonies. Furthermore, E. coli are commonly used to measure levels of antibiotic resistance in water (Reinthaler et al., 2003; Watkinson et al., 2007).

\section{Antibiotic Resistance Testing}

E. coli was isolated from beach samples using US EPA Method 10029 [(U.S. Enviornmental Protection Agency (EPA), 2002)]. Membrane filtration was employed to filter water samples and then $\mathrm{m}$-ColiBlue $24^{\circledR}$ agar (MD Millipore Corporation, Billerica, MA) was used to isolate E. coli. From the positive plates, up to 10 colonies with blue colony morphologies characteristic of E. coli were isolated per sample. These selected bacteria were streaked to isolation on tryptic soy agar then each isolate was tested for antibiotic resistance using the Kirby-Bauer disk diffusion method according to the Clinical Laboratory Standards Institute (CLSI) guidelines [(Clinical Laboratory Standards Institute (CLSI), 2012)]. The guidelines were established based on testing of clinical isolates however there are no equivalent standards for environmental isolates. Furthermore, using these standards allows for comparison to other published papers that report results of resistance analysis, including other papers that test environmental $E$. coli (Reinthaler et al., 2003; Chen et al., 2011; Holvoet et al., 2013; Skariyachan et al., 2015). Five classes of antibiotics commonly used in human medicine were included in the antibiotic resistance testing, including beta-lactams (ampicillin, $10 \mu \mathrm{g}$ ), fluoroquinolones (ciprofloxacin, $5 \mu \mathrm{g}$ ), aminoglycosides (gentamicin, $10 \mu \mathrm{g}$ ), tetracyclines (tetracycline, $30 \mu \mathrm{g}$ ), and sulfonamides (trimethoprim/sulfamethoxazole, 1.25/23.75 $\mu \mathrm{g}$ ).

\section{Statistical Analysis}

In order to normalize the distribution of the data each Enterococcus count was log transformed. An ANOVA with Bonferroni correction was performed to determine if there were any significant differences between Enterococcus counts on sample beaches. For the purposes of calculations, all values that were below the lower detection limit $(<10 \mathrm{MPN} / 100 \mathrm{~mL})$ were classified as 1 and all values that were above the upper detection limit (>24,196 MPN/100 mL) were classified as 24,196. These

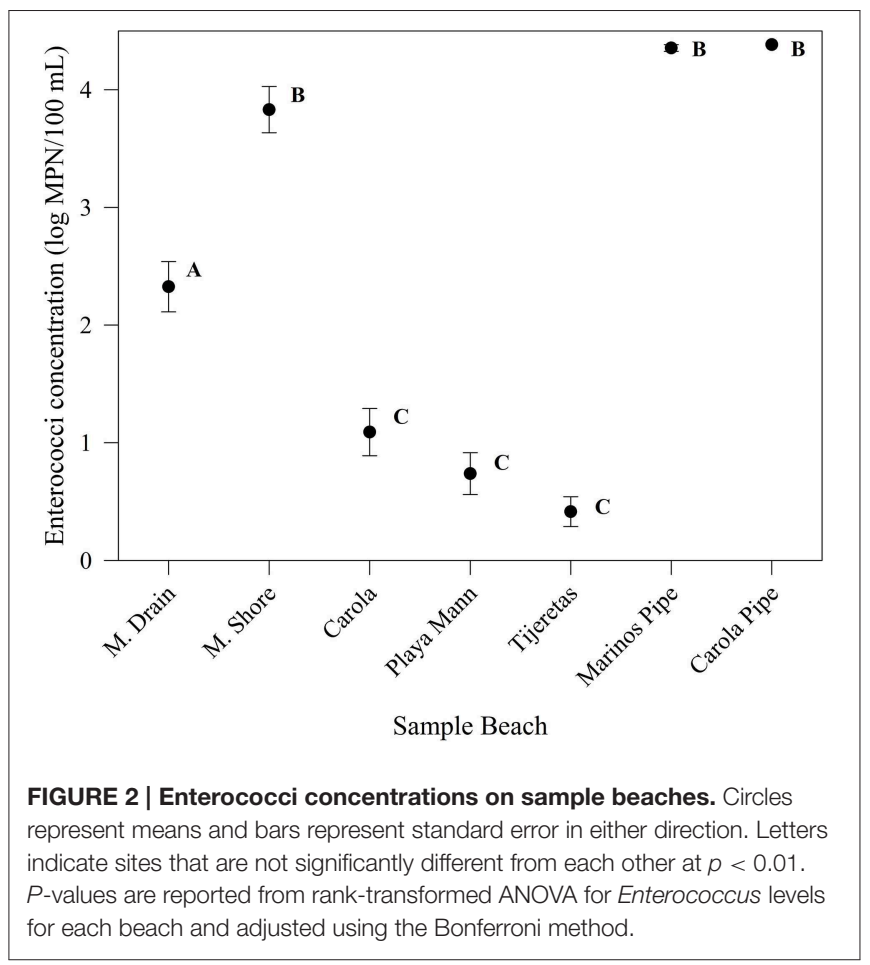

analyses were performed in SigmaPlot ver. 3.5 (Aspire Software International, Ashburn, VA).

Pearsons' chi-squared tests were performed to test for differences in (1) the proportion of antibiotic resistant E. coli and (2) the proportion of E. coli that exhibited multidrug resistance among the seven sample sites. For the purposes of these calculations, E. coli isolates that exhibited intermediate resistance were classified as susceptible (Stewart et al., 2014). All chi-square tests were performed on quantpsy.org, an online tool for chi-square tests of goodness of fit and independence (Preacher, 2015).

\section{Results}

The highest concentrations of Enterococcus were observed at the two sewage discharge sites (Marinos Pipe and Carola Pipe) and the two beaches nearest sewage discharge, M. Shore, and M. Drain (Table 1). The sites with the lowest recorded Enterococcus counts were the three sites furthest from sewage discharge: Carola, Playa Mann, and Tijeretas.

Sites further from sewage discharge (Carola, Playa Mann, Tijeretas) showed significantly lower $(p<0.01)$ Enterococcus concentrations than sites closest to sewage discharge (M. Shore, M. Drain, Marinos Pipe, and Carola Pipe) (Figure 2). Enterococcus concentrations at M. Drain, which also is the site of a land drainage canal, were significantly lower $(p<0.01)$ than those at M. Shore, Marinos Pipe, and Carola Pipe. The mean Enterococcus concentration at $\mathrm{M}$. Shore was not significantly different than Marinos Pipe, which is the nearest point of sewage discharge $(p>0.01)$. 
TABLE 1 | Enterococcus concentrations at each sample beach.

\begin{tabular}{|c|c|c|c|c|c|}
\hline $\begin{array}{l}\text { Site type and relative distance }{ }^{a} \text { to } \\
\text { sewage outfall ( } 1 \text { closest, } 5 \\
\text { furthest) }\end{array}$ & Sample site & $\begin{array}{l}\text { Latitude (decimal degrees), } \\
\text { longitude (decimal degrees) }\end{array}$ & $\begin{array}{l}\text { Samples tested for } \\
\text { Enterococcus }(N)\end{array}$ & $\begin{array}{l}\text { Site mean }{ }^{b}(\log \\
\text { MPN/100 mL) }\end{array}$ & $\begin{array}{c}\text { Standard error (log } \\
\text { MPN/100 mL) }\end{array}$ \\
\hline \multirow[t]{3}{*}{ Beach 1} & M. Shore ${ }^{C}$ & & 14 & 3.83 & 0.20 \\
\hline & Site 1 & $-0.902489^{\circ},-89.613305^{\circ}$ & 8 & & \\
\hline & Site 2 & $-0.902450^{\circ},-89.613070^{\circ}$ & 6 & & \\
\hline \multirow[t]{3}{*}{ Beach 2} & M. Drain ${ }^{C}$ & & 14 & 2.33 & 0.21 \\
\hline & Site 1 & $-0.903134^{\circ},-89.613043^{\circ}$ & 8 & & \\
\hline & Site 2 & $-0.902919^{\circ},-89.613026^{\circ}$ & 6 & & \\
\hline \multirow[t]{3}{*}{ Beach 3} & Carolac & & 16 & 1.09 & 0.20 \\
\hline & Site 1 & $-0.890460^{\circ},-89.612143^{\circ}$ & 8 & & \\
\hline & Site 2 & $-0.890799^{\circ},-89.612184$ & 8 & & \\
\hline \multirow[t]{3}{*}{ Beach 4} & Playa MannC & & 15 & 0.74 & 0.18 \\
\hline & Site 1 & $-0.895511^{\circ},-89.609542^{\circ}$ & 7 & & \\
\hline & Site 2 & $-0.895759^{\circ},-89.609538^{\circ}$ & 8 & & \\
\hline Beach 5 & Tijeretas & $-0.888161^{\circ},-89.608282^{\circ}$ & 16 & 0.41 & 0.13 \\
\hline Sewage pipe & Marinos pipe & $-0.902059^{\circ},-89.612691^{\circ}$ & 3 & 4.36 & 0.03 \\
\hline Sewage pipe & Carola pipe & $-0.888910^{\circ},-89.612691^{\circ}$ & 3 & $4.38^{d}$ & $0.00^{e}$ \\
\hline
\end{tabular}

Pearson's chi-squared test revealed that there was a significant difference $(p<0.01)$ between the proportion of $E$. coli that were resistant to one or more antibiotics on each beach $\left(\chi^{2}=34.55\right.$, $\mathrm{df}=7)$. At Marinos Pipe and Carola Pipe, all tested E. coli were resistant to at least one antibiotic (Figure 3). Excluding these sites, M. Shore had the highest percentage of E. coli resistant to at least one antibiotic (88\%), which was higher than the percentage of antibiotic-resistant E. coli in the raw sewage sample (65\%). Playa Mann, located away from sewage discharge, had the lowest percentage of antibiotic-resistant E. coli (13\%).

Pearson's chi-squared test revealed that there was a significant difference $(p<0.01)$ in the proportion of multidrug-resistant $E$. coli among sample sites $\left(\chi^{2}=41.91, \mathrm{df}=7\right)$. With the exception of the two sample pipes where $100 \%$ of tested isolates showed multi-drug resistance, $M$. Drain had the highest percentage of multidrug-resistant E. coli isolates (58\%). Thirty-five percent of $E$. coli from the raw sewage sample were multidrug-resistant, while no multidrug-resistant E. coli were collected from Carola, Playa Mann and Tijeretas (Figure 3).

\section{Discussion}

Results of this study demonstrate that water quality, using Enterococcus as an indicator, was poorest at beaches where there was the release of sewage effluent (M. Shore) or sewage effluent and land drainage (M. Drain). It is likely that human sewage is contributing to the concentrations of Enterococcus on some beaches; the significant difference between beaches near sewage outflow (M. Shore and M. Drain) and beaches not near sewage outflow (Carola, Playa Mann, Tijeretas) supports this interpretation. The higher Enterococcus levels on the beach with direct sewage effluent (M. Shore) compared to the beach near a land drainage channel (M. Drain) suggests that, compared to land runoff, sewage discharge is having a larger impact on the quality of recreational waters. Additionally, M. Drain, which is near a land drainage channel, had high variation among recorded Enterococcus concentrations. It is likely that varying precipitation, as demonstrated by Ackerman (Ackerman and Weisberg, 2003), may affect drainage to this sample beach.

The Enterococcus concentrations at sewage discharge sites reached the upper detection limit of the IDEXX Enterolert test, which is consistent with World Health Organization (WHO) studies that report levels of Enterococcus in raw sewage from $4.7 \times 10^{3}$ to $4.0 \times 10^{5}$ organisms per $100 \mathrm{~mL}$ (World Health Organization (WHO), 2003). Enterococcus concentrations on the beaches of San Cristóbal sometimes exceeded international and US regulations for water quality [(World Health Organization (WHO), 2003; U.S. Environmental Protection Agency (EPA), 2012; Ministerio del Ambiente, 2003)]. At M. Shore, every sample date exceeded recommendations, and at M. Drain $88 \%$ of samples exceeded regulations. Of the three sites primarily used for recreation, two out of eight samples at Carola and one out of eight samples at Playa Mann exceeded regulatory thresholds.

In addition to measuring concentrations of FIB, this study targeted areas with and without sewage outflow in order to investigate the potential contribution of anthropogenicallyintroduced antibiotic resistant bacteria to the environmental resistome, i.e., the collection of resistance elements in the environment (D'Costa et al., 2006). The proportion of E. coli resistant to one or more antibiotics observed in this study at sewage outflow points (100\%) and sewage impacted beaches $(88 \%)$ are similar to other studies. Sokari et al. (1988) found that 


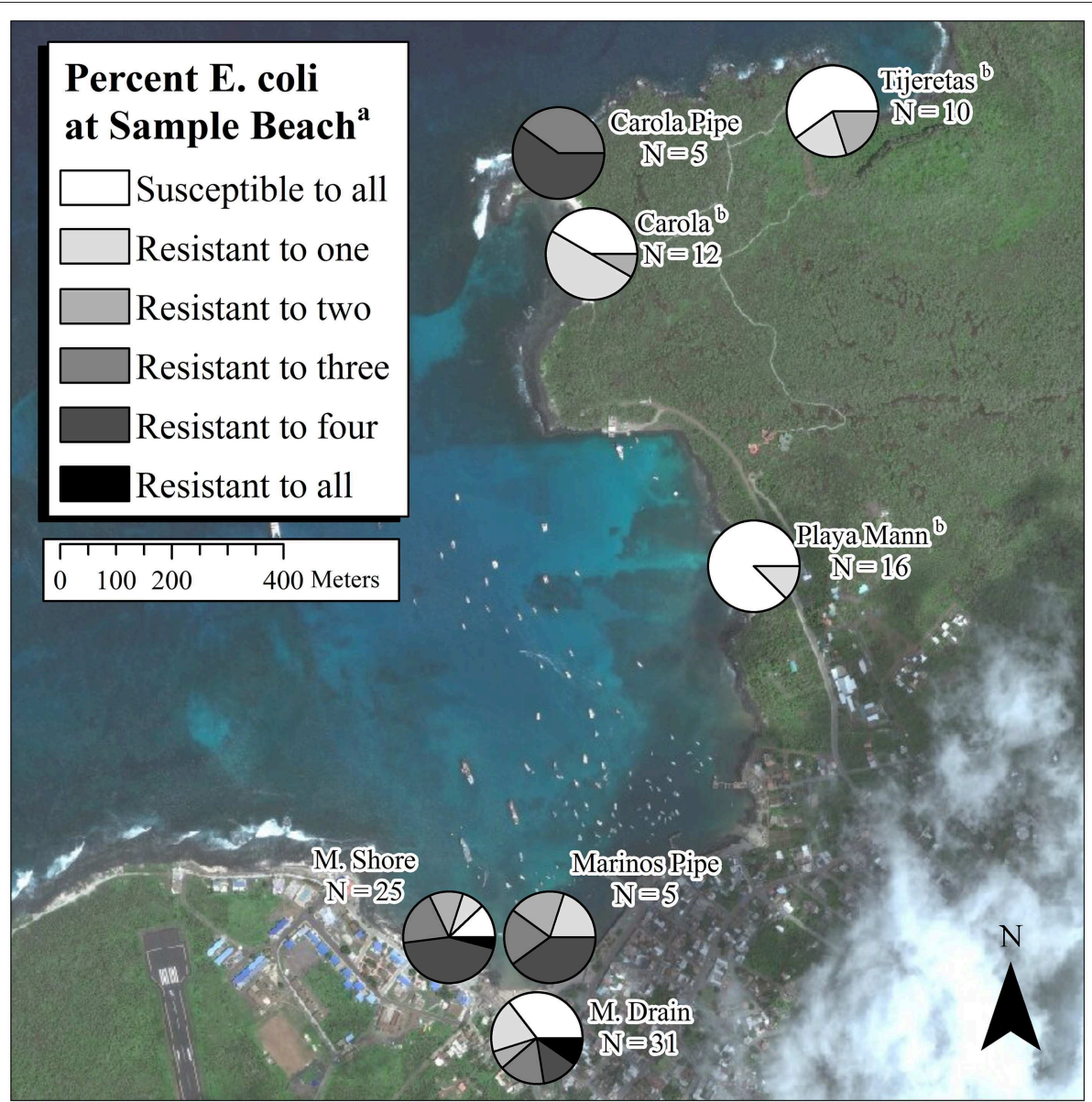

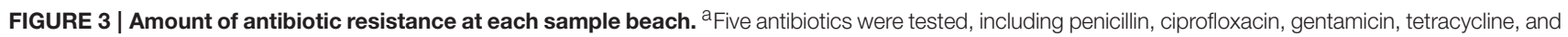
trimethoprim/ sulfamethoxazole. ${ }^{b}$ Three sites were included without sewage effluent or runoff from a developed area. $N=$ number of $E$. coli isolates tested for resistance.

about $80 \%$ of $E$. coli isolates from municipal waste, river, and estuarine waters were resistant to at least one antibiotic. Other studies have also found levels of resistance in raw sewage to be around 70\% (Cooke, 1976; Martins da Costa et al., 2006), though some studies have found resistance levels as low as 17\% (Bell, 1978).

Sewage outflow pipes (Carola Pipe and Marinos Pipe) appear to be releasing multidrug-resistant bacteria into the ocean. The significantly higher counts of antibiotic resistant E. coli at a beach near sewage outflow (M. Shore) compared to beaches without sewage (Carola, Playa Mann, and Tijeretas) suggests that these antibiotic resistant bacteria from sewage can persist in beach water. These results are consistent with the findings of Reinthaler et al. (2003), who found sewage that contained E. coli resistant to 16 of 24 tested antibiotics and concluded that sewage effluent was contributing to the dissemination of antibiotic resistant bacteria in the environment. Other studies have related antibiotic resistance in aquatic systems to inducement of resistance by heavy metals (Stepanauskas et al., 2005, 2006). However, this alternative explanation seems unlikely on San Cristobal where industrial pursuits are limited. Additionally, one of the beaches without direct sewage effluent, Carola, had a higher proportion of $E$. coli resistant to at least one antibiotic, compared to the other two beaches without sewage effluent (Playa Mann and Tijeretas). Carola is the closest of the three beaches to a sewage outfall pipe (Figure 1), so it is possible that sewage from Carola Pipe is impacting Carola even though the pipe was placed outside of the cove. It is also possible that bathers are a source of the bacteria found on these beaches, as studies have demonstrated the contribution of bather shedding to bacterial levels in recreational waters (Elmir et al., 2007; Papadopoulou et al., 2008). This would not explain the differences between Carola and the other two recreational beaches, Playa Mann, and Tijeretas; all three sites are regularly used by bathers. Unfortunately no quantitative data were available on the number of bathers at each beach but this could be an interesting variable to consider for future studies.

Although the sample size was small for testing antibiotic resistance in this study, results suggest that sewage discharge contributes to antibiotic resistance in the environment. This outcome may be particularly troublesome in tourist locations where travelers may be more likely to use antibiotics. Further sampling would provide a more complete understanding of 
environmental impacts, including the spatial and temporal extent of waterborne bacteria carrying antibiotic resistance. Additionally, the disk diffusion method only tests for phenotypic antibiotic resistance. Genotyping the resistance genes would allow for a more thorough analysis of the antibiotic resistance, including the mechanism of resistance and potentially allow for source tracking to determine the origin of the resistance. Infrastructure on the Galápagos and in Ecuador currently makes this type of analysis difficult.

The presence of FIB whose concentrations sometimes exceed international standards in the beach waters of San Cristóbal may indicate a potential health risk to locals as well as tourists who use the beaches. The presence of antibiotic resistant bacteria on beaches could pose an additional risk. Many studies have reported on the health threat posed by antibiotic resistance (Neu, 1992; Cloutier, 1995; Wise et al., 1998, 2011). Further concern is evidenced by the release of the report Antibiotic Resistance Threats in the United States in 2013 by the US Centers for Disease Control [Centers for Disease Control and Prevention (CDC), 2013] and the Antimicrobial Resistance, Global Report on Surveillance released in 2014 by the World Health Organization [World Health Organization (WHO), 2014]. These reports provide a comprehensive review of the impacts that antibiotic resistance has on public health and suggest aggressive actions to control the threat of antibiotic resistant bacteria.

The findings of this study agree with the conclusion of Walsh et al. (2010) that population growth on the Galápagos may be threatening not only the natural environment, but potentially public health on the Islands. This study is the first to examine the presence of antibiotic resistance in sewage and recreational water

\section{References}

Ackerman, D., and Weisberg, S. (2003). Relationship between rainfall and beach bacterial concentrations on Santa Monica bay beaches. J Water Health 1, 85-89. Available online at: http://www.iwaponline.com/jwh/001/2/default.htm

Al-Bahry, S. N., Mahmoud, I. Y., Al-Belushi, K. I. A., Elshafie, A. E., Al-Harthy, A., and Bakheit, C. K. (2009). Coastal sewage discharge and its impact on fish with reference to antibiotic resistant enteric bacteria and enteric pathogens as bio-indicators of pollution. Chemosphere 77, 1534-1539. doi: 10.1016/j.chemosphere.2009.09.052

Almeida, C. A., Quintar, S., González, P., and Mallea, M. A. (2007). Influence of urbanization and tourist activities on the water quality of the Potrero de los Funes River (San Luis - Argentina). Environ. Monit. Assess. 133, 459-65. doi: 10.1007/s10661-006-9600-3

Baquero, F., Martínez, J.-L., and Cantón, R. (2008). Antibiotics and antibiotic resistance in water environments. Curr. Opin. Biotechnol. 19, 260-265. doi: 10.1016/j.copbio.2008.05.006

Bell, R. B. (1978). Antibiotic resistance patterns of fecal coliforms isolated from domestic sewage before and after treatment in an aerobic lagoon. Can. J. Microbiol. 24, 886-888.

Bossart, G. D., Brawner, T. A., Cabal, C., Kuhns, M., Eimstad, E. A., Caron, J., et al. (1990). Hepatitis B-like infection in a Pacific whitesided dolphin (Lagenorhynchus obliquidens). J. Am. Vet. Med. Assoc. 196, 127-130.

Centers for Disease Control and Prevention (CDC). (2013). Antibiotic Resistance Threats in the United States. Atlanta, GA: US CDC. Available online at: http:// www.cdc.gov/drugresistance/threat-report- 2013 (Accessed Sept 30, 2015). on the Galápagos Islands. Although we conclude that sewage discharge is contributing to water degradation and antibiotic resistant E. coli in coastal waters, it is important to note that this problem is not unique to the Galápagos. Degradation of recreational and surface waters by sewage has been documented in many locations across the globe (Crowther et al., 2001; Almeida et al., 2007; Watkinson et al., 2007; Al-Bahry et al., 2009). Here we demonstrate persistence of antibiotic resistant bacteria in beach waters subject to sewage discharge and speculate that this may be problematic in areas where tourists frequently carry and use antibiotics. Others have previously suggested that waste streams from hospitals and industry may introduce antibiotic resistant bacteria to the environment. We suggest considering tourist locations as an addition to this list.

\section{Funding}

Support for KO was provided by the UNC Center for Global Initiatives Vimy Global Team Award and the UNC Office of Undergraduate Research Summer Undergraduate Research Fellowship (SURF) Program. SH was supported by the National Science Foundation Graduate Research Fellowship Program, Award Number DGE-1144081. Additional support was provided by the UNC Center for Galápagos Studies.

\section{Acknowledgments}

We would like to acknowledge Billy Gerhard, Sharon Jiang, and Danelle Dupong for their assistance in collecting and analyzing samples, and Shannon Steel for spatial analysis and GIS assistance.
Centers for Disease Control and Prevention (CDC). (2014). Health Information for Travelers to Ecuador, Including the Galápagos Islands [Internet]. Atlanta, GA: US CDC. Available online at: http://wwwnc.cdc.gov/travel/destinations/ ecuador/traveler/packing-list (Accessed Aug 21, 2015).

Chen, B., Zheng, W., Yu, Y., Huang, W., Zheng, S., Zhang, Y., et al. (2011). Class 1 integrons, selected virulence genes, and antibiotic resistance in Escherichia coli isolates from the Minjiang River, Fujian Province, China. Appl. Environ. Microbiol. 77, 148-155. doi: 10.1128/AEM.01676-10

Clinical Laboratory Standards Institute (CLSI). (2012). Performance Standards for Antimicrobial Disk Susceptibilility Test; Approved Standard- Eleventh Edition, CLSI Document M02-A11. Wayne, PA: CLSI.

Cloutier, M. J. (1995). Antibiotics: mechanisms of action and the acquisition of resistance-When magic bullets lose their magic. Am. J. Pharm. Educ. 59, 167-172.

Colford, J. M., Wade, T. J., Schiff, K. C., Wright, C. C., Griffith, J. F., Sandhu, S. K., et al. (2007). Water quality indicators and the risk of illness at beaches with nonpoint sources of fecal contamination. Epidemiology 18, 27-35. doi: 10.1097/01.ede.0000249425.32990.b9

Cooke, M. D. (1976). Antibiotic resistance among coliform and fecal coliform bacteria isolated from sewage, seawater, and marine shellfish. Antimicrob. Agents Chemother. 9, 879-884.

Cosgrove, S. E., and Carmeli, Y. (2003). The impact of antimicrobial resistance on health and economic outcomes. Clin. Infect. Dis. 36, 1433-1437. doi: $10.1086 / 375081$

Crowther, J., Kay, D., and Wyer, M. D. (2001). Relationships between microbial water quality and environmental conditions in coastal recreational waters: 
the fylde coast, UK. Water Res. 35, 4029-4038. doi: 10.1016/S0043-1354(01) 00123-3

D'Costa, V. M., McGrann, K. M., Hughes, D. W., and Wright, G. D. (2006). Sampling the antibiotic resistome. Science 311, 374-378. doi: 10.1126 /science. 1120800

deGroot, R. (1983). Tourism and conservation in the Galapagos Islands. Biol. Conserv. 26, 291-300. doi: 10.1016/0006-3207(83)90093-9

Dwight, R. H., Baker, D. B., Semenza, J. C., and Olson, B. H. (2004). Health effects associated with recreational coastal water use: urban versus rural California. Am. J. Public Health 94, 565-567. doi: 10.2105/AJPH.94.4.565

Elmir, S. M., Wright, M. E., Abdelzaher, A., Solo-Gabriele, H. M., Fleming, L. E., Miller, G., et al. (2007). Quantitative evaluation of bacteria released by bathers in a marine water. Water Res. 41, 3-10. doi: 10.1016/j.watres.2006.10.005

Epler, B. (2007).Tourism, the Economy, Population Growth, and Conservation in Galapagos. Puerto Ayora: Charles Darwin Research Foundation.

Ferguson, D. M., Griffith, J. F., McGee, C. D., Weisberg, S. B., and Hagedorn, C. (2013). Comparison of enterococcus species diversity in marine water and wastewater using enterolert and EPA method 1600. J. Environ. Public Health. 2013:848049. doi: 10.1155/2013/848049

Fewtrell, L., and Kay, D. (2015). Recreational water and infection: a review of recent findings. Curr. Environ. Health Rep. 2, 85-94. doi: 10.1007/s40572-0140036-6

Fleisher, J. M., Kay, D., Wyer, M. D., and Godfree, A. F. (1998). Estimates of the severity of illnesses associated with bathing in marine recreational waters contaminated with domestic sewage. Int. J. Epidemiol. 27, 722-726.

Fleming, L. E., Broad, K., Clement, A., Dewailly, E., Elmir, S., Knap, A., et al. (2006). Oceans and human health: emerging public health risks in the marine environment. Mar. Pollut. Bull. 53, 545-560. doi: 10.1016/j.marpolbul.2006.08.012

Galapagos National Park Service. (2010). Informe de Ingreso de Turistas. Puerto Ayora, Santa Cruz, CA: Galapagos National Park.

Giske, C. G., Monnet, D. L., Cars, O., and Carmeli, Y. (2008). Clinical and economic impact of common multidrug-resistant gram-negative bacilli. Antimicrob. Agents Chemother. 52, 813-821. doi: 10.1128/AAC.01169-07

Guardabassi, L., Petersen, A., Olsen, J. E., and Dalsgaard, A. (1998). Antibiotic resistance in Acinetobacter spp. isolated from sewers receiving waste effluent from a hospital and a pharmaceutical plant. Appl. Environ. Microbiol. 64, 3499-3502.

Hernández, M., Robinson, I., Aguilar, A., González, L. M., López-Jurado, L. F., Reyero, M. I., et al. (1998). Did algal toxins cause monk seal mortality. Nature 393, 28-29.

Holvoet, K., Sampers, I., Callens, B., Dewulf, J., and Uyttendaele, M. (2013). Moderate prevalence of antimicrobial resistance in Escherichia coli isolates from lettuce, irrigation water, and soil. Appl. Environ. Microbiol. 79, 6677-6683. doi: 10.1128/AEM.01995-13

Howarth, R., Sharpley, A., and Walker, D. (2002). Sources of nutrient pollution to coastal waters in the United States: implications for achieving coastal water quality goals. Estuaries 25, 656-676. doi: 10.1007/ BF02804898

Huycke, M. M., Sahm, D. F., and Gilmore, M. S. (1998). Multiple-drug resistant Enterococci: the nature of the problem and an agenda for the future. Emerg. Infect. Dis. 4, 239-249.

Jackson, J. B., Kirby, M. X., Berger, W. H., Bjorndal, K. A., Botsford, L. W., Bourque, B. J., et al. (2001). Historical overfishing and the recent collapse of coastal ecosystems. Science 293, 629-637. doi: 10.1126/science.10 59199

Jain, S., and Marothi, Y. A (2014). Study of antimicrobial resistance in clinical isolates of Enterococci. Natl. J. Integra. Res. Med. 5, 81-87.

Kim, S., and Aga, D. S. (2007). Potential ecological and human health impacts of antibiotics and antibiotic-resistant bacteria from wastewater treatment plants. J. Toxicol. Environ. Health B Crit. Rev. 10, 559-573. doi: 10.1080/15287390600975137

Magiorakos, A. P., Srinivasan, A., Carey, R. B., Carmeli, Y., Falagas, M. E., Giske, C. G., et al. (2011). Multidrug-resistant, extensively drug-resistant and pandrug-resistant bacteria: an international expert proposal for interim standard definitions for acquired resistance. Clin. Microbiol. Infect. 18, 268-281. doi: 10.1111/j.1469-0691.2011.03570.x

Martins da Costa, P., Vaz-Pires, P., and Bernardo, F. (2006). Antimicrobial resistance in Enterococcus spp. isolated in inflow, effluent and sludge from municipal sewage water treatment plants. Water Res. 40, 1735-1740. doi: 10.1016/j.watres.2006.02.025

Ministerio del Ambiente. (2003). Texto Unificado de Legislación Ambiental Secundaria (TULSMA). Quito: Ministerio del Ambiente de Ecuador.

Neu, H. (1992). The crisis in antibiotic resistance. Science 257, 1064-1073.

Nixon, S. (1995). Coastal marine eutrophication: a definition, social causes, and future concerns. Ophelia 41, 199-219. doi: 10.1080/00785236.1995.10422044

Okeke, I. N., Lamikanra, A., and Edelman, R. (1999). Socioeconomic and behavioral factors leading to acquired bacterial resistance to antibiotics in developing countries. Emerg. Infect. Dis. 5, 18-27.

Papadopoulou, C., Economou, V., Sakkas, H., Gousia, P., Giannakopoulos, X., Dontorou, C., et al. (2008). Microbiological quality of indoor and outdoor swimming pools in Greece: investigation of the antibiotic resistance of the bacterial isolates. Int. J. Hyg. Environ. Health 211, 385-97. doi: 10.1016/j.ijheh.2007.06.007

Parveen, S., Murphree, R. L., Edmiston, L., Kaspar, C. W., Portier, K. M., and Tamplin, M. L. (1997). Association of multiple-antibiotic-resistance profiles with point and nonpoint sources of Escherichia coli in Apalachicola Bay. Appl. Environ. Microbiol. 63, 2607-2612.

Preacher, K. J. (2015). Calculation for the Chi-square test: An Interactive Calculation Tool for chi-square Tests of Goodness of Fit and Independence [Internet]. Nashville, TN: Vanderbilt University, Quantitative Methods Program. Available online at: http://quantpsy.org (Accessed Aug 21, 2015).

Prüss, A. (1998). Review of epidemiological studies on health effects from exposure to recreational water. Int. J. Epidemiol. 27, 1-9.

Reinthaler, F. F., Posch, J., Feierl, G., Wüst, G., Haas, D., Ruckenbauer, G., et al. (2003). Antibiotic resistance of E. coli in sewage and sludge. Water Res. 37, 1685-1690. doi: 10.1016/S0043-1354(02)00569-9

Richter, L. K. (2003). International tourism and its global public health consequences. J. Travel Res. 41, 340-347. doi: 10.1177/00472875030410 04002

Roberts, R. R., Hota, B., Ahmad, I., Scott, R. D., Foster, S. D., Abbasi, F., et al. (2009). Hospital and societal costs of antimicrobial-resistant infections in a Chicago teaching hospital: implications for antibiotic stewardship. Clin. Infect. Dis. 49, 1175-1184. doi: 10.1086/605630

Schwartz, T., Kohnen, W., Jansen, B., and Obst, U. (2003). Detection of antibiotic-resistant bacteria and their resistance genes in wastewater, surface water, and drinking water biofilms. FEMS Microbiol. Ecol. 43, 325-335. doi: 10.1111/j.1574-6941.2003.tb01073.x

Shahidul Islam, M., and Tanaka, M. (2004). Impacts of pollution on coastal and marine ecosystems including coastal and marine fisheries and approach for management: a review and synthesis. Mar. Pollut. Bull. 48, 624-649. doi: 10.1016/j.marpolbul.2003.12.004

Silbergeld, E. K., Graham, J., and Price, L. B. (2008). Industrial food animal production, antimicrobial resistance, and human health. Annu. Rev. Public Health 29, 151-169. doi: 10.1146/annurev.publhealth.29.020907. 090904

Skariyachan, S., Mahajanakatti, A. B., Grandhi, N. J., Prasanna, A., Sen, B., Sharma, N., et al. (2015). Environmental monitoring of bacterial contamination and antibiotic resistance patterns of the fecal coliforms isolated from Cauvery River, a major drinking water source in Karnataka, India. Environ. Monit. Assess. 187:279. doi: 10.1007/s10661-015-4488-4

Sokari, T. G., Ibiebele, D. D., and Ottih, R. M. (1988). Antibiotic resistance among coliforms and Pseudomonas spp. from bodies of water around Port Harcourt, Nigeria. J. Appl. Bacteriol. 64, 355-359.

Stepanauskas, R., Glenn, T. C., Jagoe, C. H., Tuckfield, R. C., Lindell, A. H., King, C. J., et al. (2006). Coselection for microbial resistance to metals and antibiotics in freshwater microcosms. Environ. Microbiol. 8, 1510-1514. doi: 10.1111/j.1462-2920.2006.01091.x

Stepanauskas, R., Glenn, T. C., Jagoe, C. H., Tuckfield, R. C., Lindell, A. H., and McArthur, J. V. (2005). Elevated microbial tolerance to metals and antibiotics in metal-contaminated industrial environments. Environ. Sci. Technol. 39, 3671-3678. doi: 10.1021/es048468f

Stewart, J. R., Townsend, F. I., Lane, S. M., Dyar, E., Hohn, A. A., Rowles, T. K., et al. (2014). Survey of antibiotic-resistant bacteria isolated from bottlenose dolphins Tursiops truncatus in the southeastern USA. Dis. Aquat. Organ. 108, 91-102. doi: 10.3354/dao02705

U.S. Enviornmental Protection Agency (EPA). (2002). Method 10029: Total Coliforms and E. coli Membrane Filtration Method. Washington, DC: US EPA. 
U.S. Environmental Protection Agency (EPA). (2012). Recreational Water Quality Criteria, Report No: EPA 820-F-12-058. Washington, DC: US EPA.

Wade, T. J., Pai, N., Eisenberg, J. N. S., and Colford, J. M. (2003). Do U.S. Environmental Protection Agency Water Quality Guidelines for Recreational Waters Prevent Gastrointestinal Illness? A Systematic Review and Meta-analysis. Environ. Health Perspect. 111, 1102-1109. doi: 10.1289/ ehp.6241

Walsh, S. J., McCleary, A. L., Heumann, B. W., Brewington, L., Raczkowski, J., Mena, C. F., et al. (2010). Community expansion and infrastructure development: implications for human health and environmental quality in the Galápagos Islands of Ecuador. J. Lat. Am. Geogr. 9, 137-159. doi: 10.1353/lag.2010.0024

Watkins, G., and Cruz, F. (2007). Galapagos at risk A Socioeconomic Analysis of the Situation in the Archipelago. Puerto Ayora: Charles Darwin Research Foundation.

Watkinson, A. J., Micalizzi, G. B., Graham, G. M., Bates, J. B., and Costanzo, S. D. (2007). Antibiotic-resistant Escherichia coli in wastewaters, surface waters, and oysters from an urban riverine system. Appl. Environ. Microbiol. 73, 5667-5670. Doi: 10.1128/AEM.00763-07

Wise, R., Blaser, M., Carrs, O., Cassell, G., Fishman, N., Guidos, R., et al. (2011). The urgent need for new antibacterial agents. J. Antimicrob. Chemother. 66, 1939-1940. doi: 10.1093/jac/dkr261
Wise, R., Hart, T., Cars, O., Streulens, M., Helmuth, R., Huovinen, P., et al. (1998). Antimicrobial resistance is a major threat to public health. BMJ 317, 609-610.

World Health Organization (WHO). (2003). Guidelines for Safe Recreational Water Environments. Vol. 1, Coastal and Fresh Waters. Geneva: WHO. Available online at: http://apps.who.int/iris/bitstream/ 10665/42591/1/9241545801.pdf (Accessed Sept 30, 2015).

World Health Organization (WHO). (2014). Antimicrobial Resistance Global Report on Surveillance. Geneva: WHO. Available online at: http://apps.who. int/iris/bitstream/10665/112642/1/9789241564748_eng.pdf (Accessed Sept 30, 2015).

Conflict of Interest Statement: The authors declare that the research was conducted in the absence of any commercial or financial relationships that could be construed as a potential conflict of interest.

Copyright (c) 2015 Overbey, Hatcher and Stewart. This is an open-access article distributed under the terms of the Creative Commons Attribution License (CC BY). The use, distribution or reproduction in other forums is permitted, provided the original author(s) or licensor are credited and that the original publication in this journal is cited, in accordance with accepted academic practice. No use, distribution or reproduction is permitted which does not comply with these terms. 